\title{
First continental troglobiont Cylindroiulus millipede (Diplopoda, Julida, Julidae)
}

\author{
Ana Sofia P.S. Reboleira', Henrik Enghoff' \\ I Natural History Museum of Denmark, University of Copenhagen, Universitetsparken 15, DK-2100 Koben- \\ havn Ø, Denmark \\ Corresponding author: Ana Sofia P.S. Reboleira (sreboleira@snm.ku.dk)
}

Academic editor: Nesrine Akkari | Received 20 June 2018 | Accepted 25 September 2018 | Published 8 November 2018

http://zoobank.org/EC1CAED3-DAAC-4AE7-8779-44DB3164EECE

Citation: Reboleira ASPS, Enghoff H (2018) First continental troglobiont Cylindroiulus millipede (Diplopoda, Julida, Julidae). ZooKeys 795: 93-103. https://doi.org/10.3897/zookeys.795.27619

\begin{abstract}
The new species of millipede Cylindroiulus villumi is described from a cave in the Estremenho karst massif in central Portugal. It is the first cave-adapted species of its genus with a strict subterranean life-style in continental Europe, and is the fifth blind species of the genus. The new species is illustrated with photographs and diagrammatic drawings. It is tentatively placed in the purely Iberian Cylindroiulus perforatus-group. The differences between the new species and its relatives are discussed, as well as its adaptations to a subterranean life-style.
\end{abstract}

\section{Keywords}

cave fauna, Julida, karst, Portugal, troglobiont

\section{Introduction}

The genus Cylindroiulus Verhoeff, 1894 belongs to the Palaeartic family Julidae and has more than 100 species distributed in Macaronesia and Europe (Kime and Enghoff 2017), North Africa (Read 2005, Akkari and Enghoff 2008), Turkey, the Caucasus region and Iran (Read 1992), and Central Asia (Read 1994). The genus can be recognized by the lack of frontal and metazonital setae, expanded mandibular stipites in males, gonopods with a flagella, and free, unforked mesomerites separated by a deep and wide incision from the opisthomerite (Read 1990).

Cave-adapted species of Cylindroiulus species were only known from Madeira Island, whereas in continental Europe only two anophthalmic, but not troglobiont, species were known (Reboleira and Enghoff 2014a, Read 2007). 
Nine species of Cylindroiulus are currently known from mainland Portugal: $C$. anglilectus Read, 2007, C. boreoibericus Read, 2007, C. britannicus (Verhoeff, 1891), C. caeruleocinctus (Wood, 1864), C. fenestratus Read, 1989, C. latestriatus (Curtis, 1845), C. perforatus Verhoeff, 1905, C. propinquus (Porat, 1870), and C. truncorum (Silvestri, 1896) (Read 2007, Kime and Enghoff 2017).

Only very recently cave-adapted species of millipedes from Portugal have started to dig out of the dark and become known to science (Enghoff and Reboleira 2013, Reboleira and Enghoff 2013a, b, 2014a, b, c, 2017). Recently, a new species of Cylindroiulus has been found in a cave in the Estremenho massif in central Portugal. This is the largest karst area of Portugal, mainly composed of Jurassic limestone; a considerable part of its area is included in the Serra de Aire e Candeeiros Natural Park. We here describe this first cave-adapted species of Cylindroiulus from the European continent.

\section{Materials and methods}

Sampling was performed by direct search in the cave Algar do Pena in Estremenho karst massif, central Portugal.

Specimens were examined under a binocular stereomicroscope Leica M165C, and measurements were made with the software Leica Application Suite V4.12. Gonopods, vulvae, legs and antennae were dissected and mounted on temporary slides in glycerine or lactic acid for study under light microscopy in a Leica DM2500 microscope. Measurements were made following the methodology described by Enghoff (1982). Images of the gonopods and vulvae were stacked with the software Zerene Stacker. For scanning electron microscopy (SEM) one head, gonopod, leg, and tail were mounted on aluminium stubs, coated for 110 seconds with platinum/palladium, and studied in a JEOL JSM-6335F microscope. The background of some SEM images was processed with Adobe Photoshop CS6.

The type material is deposited in the collection of the Natural History Museum of Denmark, University of Copenhagen (NHMD, formerly ZMUC).

\section{Results}

Order Julida Brandt, 1833

Family Julidae Leach, 1814

Genus Cylindroiulus Verhoeff, 1894

\section{Cylindroiulus villumi sp. $\mathrm{n}$.}

http://zoobank.org/79A57B30-7ABF-4FCB-9B94-CB0A459DB129

Figs $1-5$

Type material. Holotype, male, Portugal, Estremenho karst massif, Algar do Pena Cave (Coordinates: $\left.39^{\circ} 27^{\prime} 54.40^{\prime \prime} \mathrm{N}, 8^{\circ} 48^{\prime} 25.24 " \mathrm{~W}\right)$, ASPS Reboleira leg., 04 Nov 

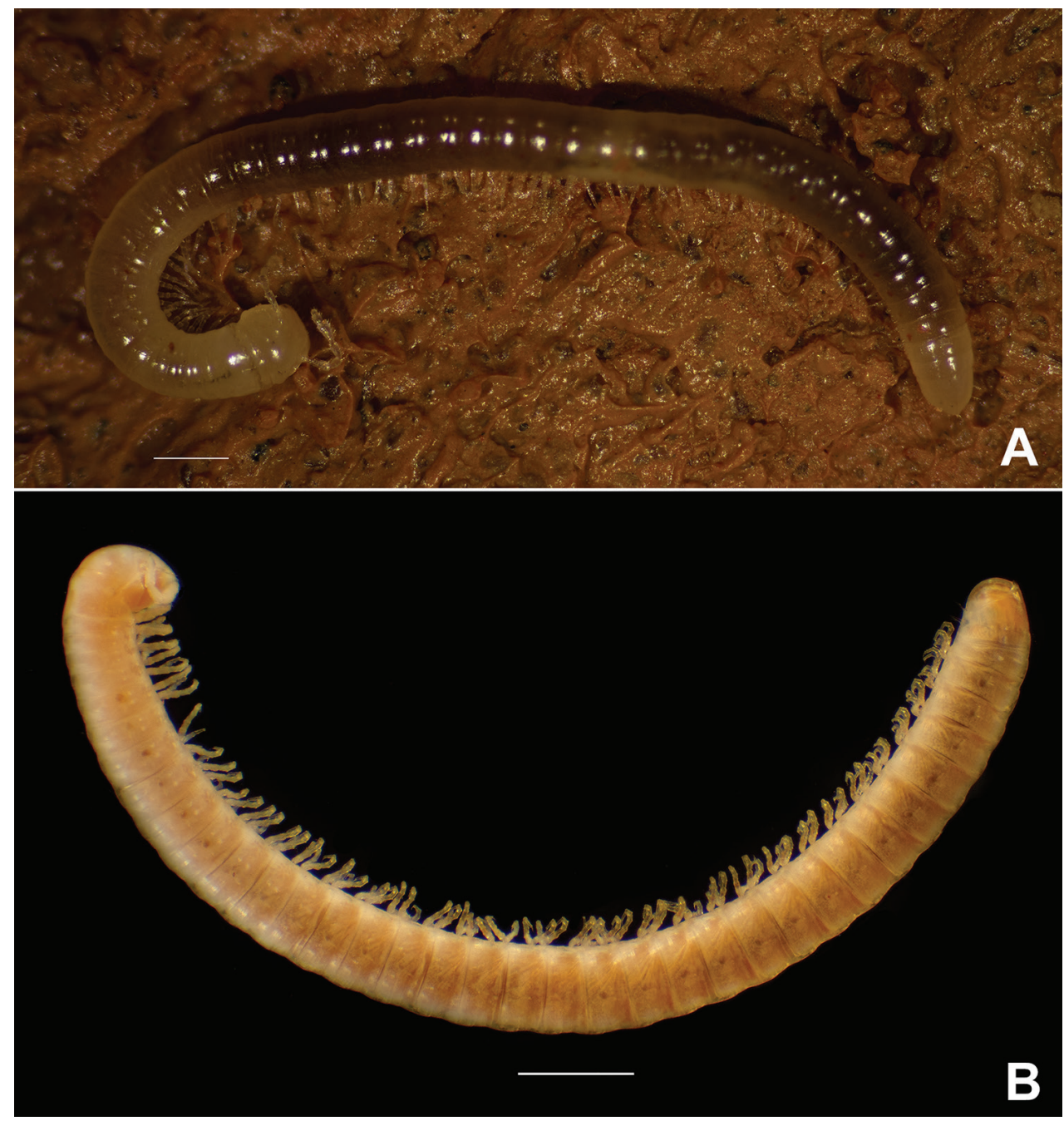

Figure I. Cylindroiulus villumi sp. n. A habitus of live female B habitus of subadult male. The partly darker colouration in $1 \mathrm{~B}$ is due to gut contents seen by transparency. Scale bar: $1 \mathrm{~mm}$.

2014. Paratypes: Portugal, Estremenho karst massif, Algar do Pena Cave, ASPS Reboleira leg., 04 Nov 2014, 1 male, 2 females, 4 juvenile males and 1 juvenile; same data but 28 Mar 2018, 1 female and 1 juvenile.

Diagnosis. A medium to small, blind, and unpigmented species of the Cylindroiulus perforatus-group. Anterior constriction pronounced and pilosity of the telson scarce. Differs from all other species in the group by the lack of eyes and by the shape of the gonopod mesomerite which is shorter than the promerite $(><C$. fenestratus Read, 1989, C. perforatus Verhoeff, 1905, and C. ventanaea Read, 2007) and apically rounded ( $><$ C. anglilectus Read, 2007). Further differs from other group members except $C$. anglilectus by the much shorter paracoxal process. 


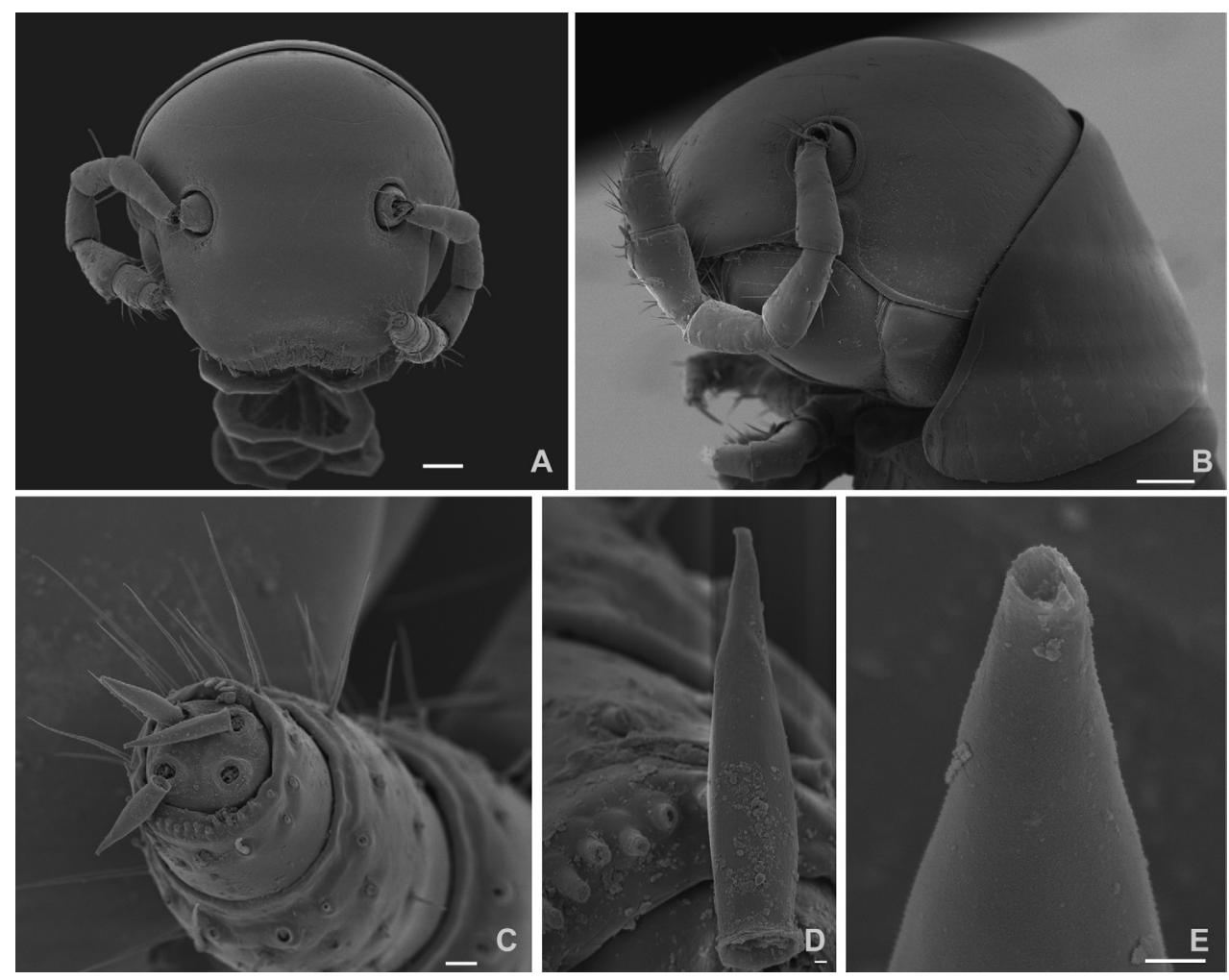

Figure 2. Cylindroiulus villumi sp. n. female paratype, SEM. A anterior view of the head B lateral view of the head $\mathbf{C}$ tip of the antenna $\mathbf{D}$ detail of a sensory cone of the antenna $\mathbf{E}$ tip of the sensory cone. Scale bars: $100 \mu \mathrm{m}(\mathbf{A}, \mathbf{B}) ; 10 \mu \mathrm{m}(\mathbf{C}) ; 1 \mu \mathrm{m}(\mathbf{D}, \mathbf{E})$.

Description. Male holotype: 37 podous +1 apodous rings + telson; females up to 41 podous +1 apodous rings + telson.

Body length up to $13 \mathrm{~mm}$ in females and $11.4 \mathrm{~mm}$ in males. Vertical body diameter (H): $0.9 \mathrm{~mm}$ (females) and $0.7 \mathrm{~mm}$ (males). Integument unpigmented (Figure 1); eyes absent (Figs 1, 2A, B). Length of antennae $0.8 \mathrm{~mm}$ (Figure 2B), with sensory cones elongated and with a fine longitudinal striation (Figure 2C, D) ending in a pore as shown in Figure 2E. Anterior constriction of body pronounced in dorsal view. Limbus of the the normal type sensu Enghoff (1982), i.e., with simple marginal cells without denticles on the free margin. Length of legs (Figure 3A) $1.8 \mathrm{~mm}$, tarsus being the longest podomere. Length of claw $9.6 \%$ of total leg length. Accessory claw exceptionally short: $92 \%$ shorter than the claw (Figure 3B). Preanal ring with a very short blunt projection, almost glabrous, only with 5 lateral setae (Figure 3C, D), subanal scale with two setae, anal valves with two long ventral setae on the lateral part of the posterior margin, rarely up to two additional setae were observed, however the number is variable and may even differ between right and left valve of the same specimen (Figure 3C). Male first pair of legs modified as typical of the genus, hook-like. 

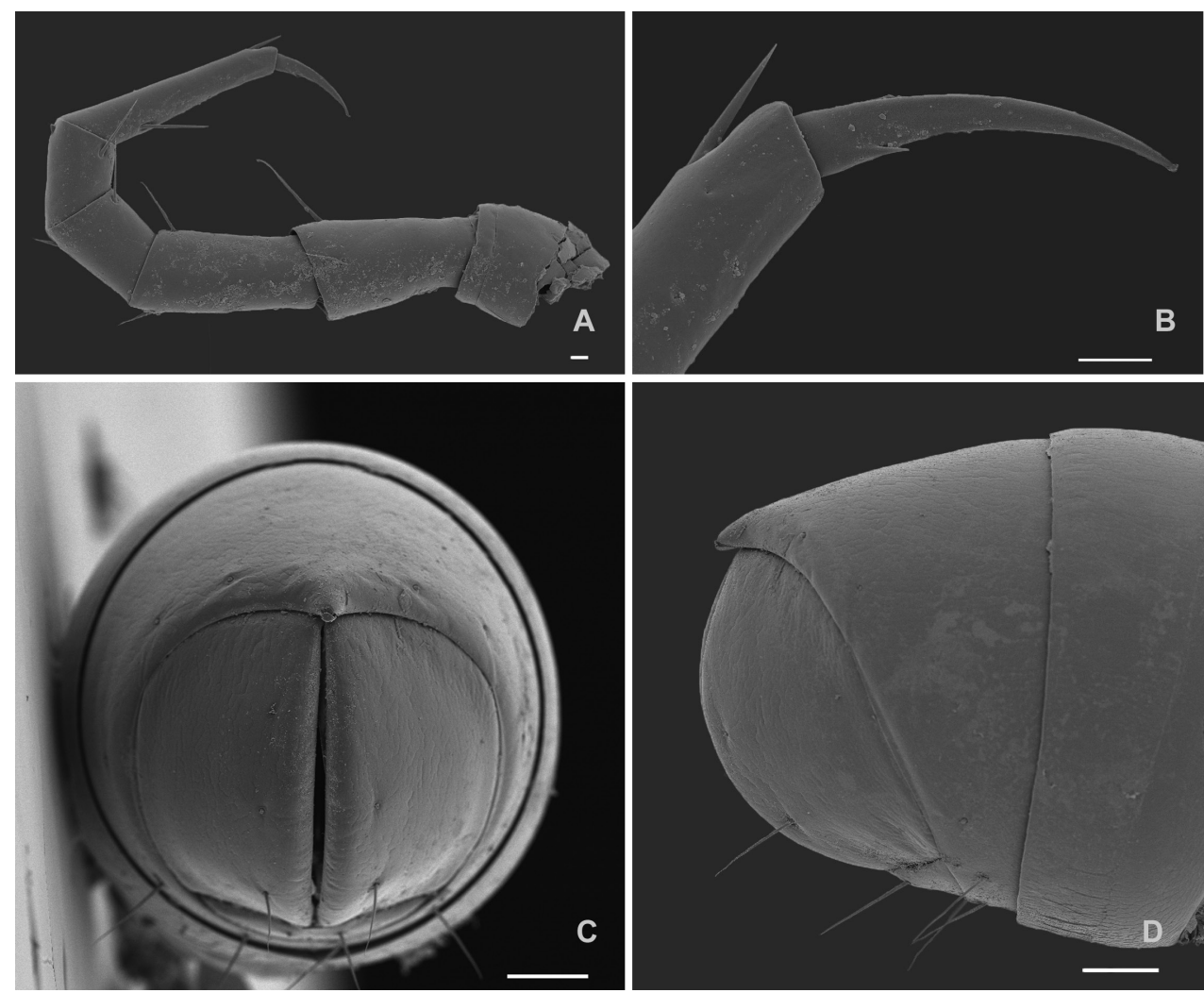

Figure 3. Cylindroiulus villumi sp. n. female paratype, SEM. A midbody leg $\mathbf{B}$ detail of the claw $\mathbf{C}$ posterior view of the anal valves $\mathbf{D}$ lateral view of the telson. Scale bars: $10 \mu \mathrm{m}(\mathbf{A}, \mathbf{B}) ; 100 \mu \mathrm{m}(\mathbf{C}, \mathbf{D})$.

Gonopods (Figure 4): Promerite in anterior view (Figure 4D), higher than mesomerite (Figure 4D, E), with rugose area facing apical part of the mesomerite (Figure 4E). Mesomerite (Figure 4E): slender, shorter than, and fitting into, apical concavity of promerite. Paracoxal rim moderately developed. Paracoxal process not very prominent, rather short and mostly fused to solenomerite (Figure 4F). Solenomerite as in Figure $4 \mathrm{~A}, \mathrm{~B}, \mathrm{C}, \mathrm{F}$; very simple, subrectangular in lateral view, with denticles on anterior flagellum-conducting lamella (Figure 4C).

Vulvae (Figure 5A-B): Vulvae typical of the C. perforatus-group: glabrous operculum, bursa with a few setae and the receptaculum seminis as a stalked sphere with a small tubular appendix.

Etymology. The new species is dedicated to the VILLUM Foundation, named after Villum Kann Rasmussen (1909-1993), as recognition for the generous support to research in natural sciences.

Distribution. Cylindroiulus villumi sp. n. was discovered in the cave Algar do Pena, located in the Santo António plateau, the central sub-unit of the Estremenho 


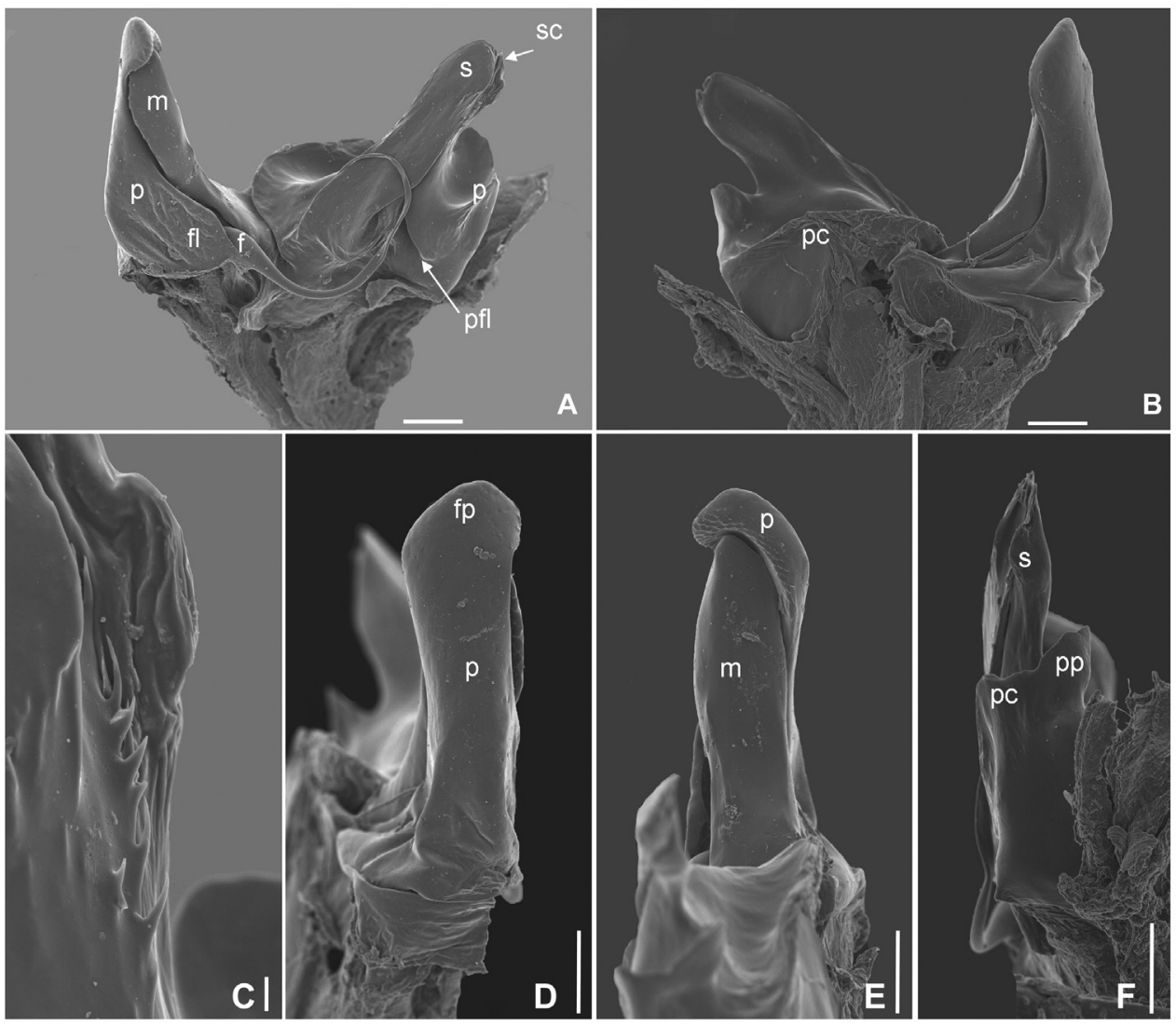

Figure 4. Cylindroiulus villumi sp. n. SEM of the male gonopod. A mesal view B lateral view $\mathbf{C}$ denticles on the anterior flagellum-conducting lamella of the solenomerite $\mathbf{D}$ pro- and mesomerite, anterior view E pro- and mesomerite, posterior view $\mathbf{F}$ opisthomerite, posterior view. Abbreviations: f: flagellum, fl: flagelliferous lobe of promerite, fp: finger-shapped projection of promerite, m: mesomerite, p: promerite, pc: lateral rim of paracoxite, pfl: posterior flagellum-conducting lamella, pp: paracoxal process, s: solenomerite, sc: sperm canal. Scale bars: $10 \mu \mathrm{m}(\mathbf{A}, \mathbf{B}, \mathbf{D}, \mathbf{E}, \mathbf{F}) ; 1 \mu \mathrm{m}(\mathbf{C})$.

karst massif in central Portugal. It was found inside a big piece of deadwood located at the base of the entrance pit to the cave, at a depth of 33 meters below the surface.

Ecology. Algar do Pena is the largest underground chamber of Portugal. The temperature is very constant $13 \pm 1{ }^{\circ} \mathrm{C}$ and relative humidity close to saturation. It is a very oligotrophic cave where only a few cave-adapted species are recorded: the spider Nesticus lusitanicus Fage, 1931, the terrestrial isopod Trichoniscoides meridionalis Vandel, 1946, the springtail Onychiurus confugiens Gama, 1962; the dipluran Podocampa cf. fragiloides Silvestri, 1932; and the beetle Trechus gamae Reboleira \& Serrano, 2009 (Reboleira 2007, 2012, Reboleira and Ortuño 2011, Reboleira et al. 2009, 2010, 2011). The holotype and a juvenile male paratype have 'Amphoromorpha' fungi on the head and antenna, similar to those observed by Enghoff and Reboleira (2017) on other millipedes. 

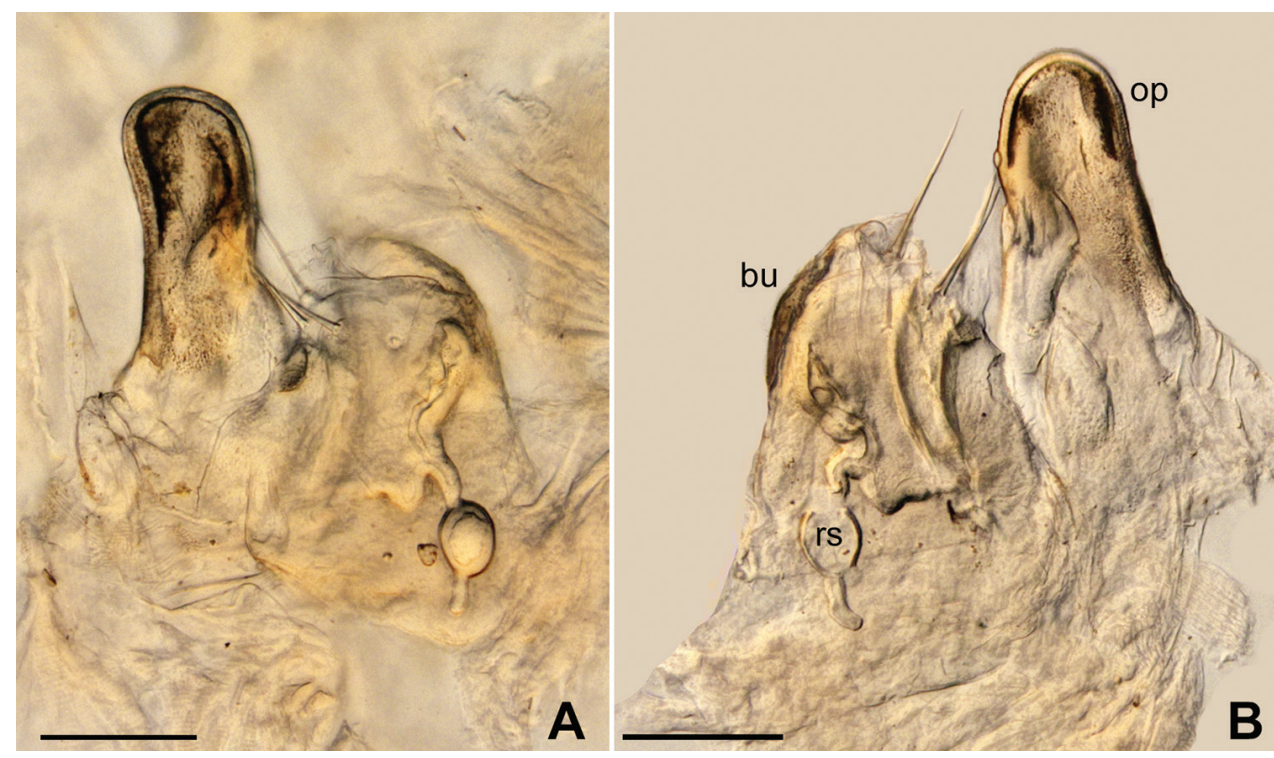

Figure 5. Cylindroiulus villumi sp. n. vulva, lateral view. Abbreviations: bu: bursa, op: operculum, rs: receptaculum seminis. Scale bar: $100 \mu \mathrm{m}$.

\section{Discussion}

The genus Cylindroiulus exhibits great morphological diversity concerning size, ocelli, number of segments, pigmentation, chaetotaxy, legs, accessory claws, and genital structures (Reboleira and Enghoff 2014c, Read 1989a, b); in the endemic C. madeirae-group from Madeira Island, part of the diversity can be seen as a result of niche segregation (Enghoff 1982, 1983, 2011). The new species C. villumi is the first representative of the genus with an exclusively subterranean life-style and corresponding troglomorphic characters (i.e., unpigmented, anophthalmic, elongated sensory cones on the antenna, and very short accessory claw) found in continental Europe. The new species can be distinguished from all congeners by the combination of anophthalmy and the shape of the male gonopods. The extremely short accessory claws, a trait believed to be associated with the ability to climb (Enghoff 1983), has also been observed in the other cave-adapted species of the genus (Reboleira and Enghoff 2014c).

Two anophthalmic, subterranean-adapted species of Cylindroiulus, C. julesvernei and C. oromii, are known from caves of Madeira Island (Reboleira and Enghoff 2014c). From the rest of the vast distribution area of Cylindroiulus, only two anophthalmic species are known: C. vulnerarius (Berlese, 1888), a species that has occasionally been found in caves but which is quite widespread in epigean soil habitats in West Europe (Schubart 1934, Kime and Enghoff 2017), and C. gregoryi Read, 2007 from the Galician province of Spain.

Cylindroiulus villumi sp. $\mathrm{n}$. belongs to the nominal subgenus Aneuloboiulus Verhoeff, 1899 which is characterized by traits regarded as plesiomorphic (Enghoff 1982, Read 2007). Within this assemblage, C. villumi sp. n. may, with some uncertainty, 
be placed in the Iberian $C$. perforatus-group. This group, which contains four Iberian species, is characterized by a "window", usually a perforation, in the gonopodal promerite; in other characters, the group is similar to the endemic Macaronesian $C$. madeira-group, notably by the presence of denticles on the flagellum-conducting lamella of the solenomerite, the naked vulvar operculum and the tubular appendix to the receptaculum seminis (Read 1989a, b, 2007). Cylindroiulus villumi does not have a perforated promite, but it does have denticles on the anterior flagellum-conducting lamella on the gonopod solenomerite like species of the C. perforatus-group; also the vulva of $C$. villumi sp. n. with the glabrous operculum and the subspherical receptaculum seminis with a small terminal appendix are typical of the $C$. perforatus-group. In these characters our new species is also similar to the Macaronesian C. madeirae-group (Enghoff 1982), presumably the sister-group of the C. perforatus-group (Read 1989a, b); however, the pilosity of the preanal ring in C. villumi sp. n. more resembles that of the C. perforatus-group.

The Algar do Pena Cave, where the new species was found, has been intensively sampled over the last decade, and only very recently this species was collected (Reboleira 2007, 2012). Several other caves in the same massif have been intensively sampled without retrieving any specimen of the new species. Only the troglophile chordeumatidan Haplobainosoma lusitanum Verhoeff, 1900 (family Haplobainosomatidae) has been recorded in caves of the same massif, while two epigean unidentified species of Cylindroiulus are also known from the mesovoid shallow substrate (MSS) in same massif (Reboleira and Enghoff 2014a).

\section{Acknowledgements}

We acknowledge the Natural Park of Serra de Aire e Candeeiros for all kinds of logistic support in fieldwork, and Josh Jenkins Shaw for English revision of the manuscript. ASR is supported by a research grant (15471) from VILLUM FONDEN. All specimens were collected under permits of the Instituto de Conservação da Natureza e das Florestas.

\section{References}

Akkari N, Enghoff H (2008) Cylindroiulus mitta n.sp., a new Tunisian millipede (Diplopoda, Julida: Julidae) and notes on the Cylindroiulus distinctus group. Zootaxa 1768: 61-68.

Berlese A (1888) Mesoiulus vulnerarius n.sp. Acari, Myriopoda et Scorpiones hucusque in Italia reperta 48(1): 1 .

Brandt IF (1833) Tentaminum quorundam monographicorum Insecta Myriapoda Chilognatha Latreillii spectantium Prodromus. Bulletin de la Société Impériale des Naturalistes de Moscou 6: 194-209. [pl 5]

Curtis J (1845) Observations on the natural history and economy of the insects called wireworms, etc. Journal of the Royal Agricultural Society of England 5(1): 180-237. 
Enghoff H (1982) The millipede genus Cylindroiulus on Madeira - an insular species swarm (Diplopoda, Julida: Julidae). Entomologica Scandinavica (Supplement No.) 18: 1-142.

Enghoff H (1983) Adaptive radiation of the millipede genus Cylindroiulus on Madeira: habitat, body size, and morphology (Diplopoda, Julida: Julidae). Revue d'écologie et de biologie du sol 20(3): 403-415.

Enghoff H (2011) The millipede genera Cylindroiulus and Dolichoiulus as examples of Macaronesian species swarms. In: Serrano ARM, Borges PAV, Boieiro M, Oromí P (Eds) Terrestrial arthropods of Macaronesia - Biodiversity, ecology and evolution. Sociedade Portuguesa de Entomologia, Lisboa, 231-247.

Enghoff H, Reboleira ASPS (2013) Subterranean species of Acipes Attems, 1937 (Diplopoda, Julida, Blaniulidae). Zootaxa 3652(4): 485-491. https://doi.org/10.11646/zootaxa.3652.4.6

Enghoff H, Reboleira ASPS (2017) Diversity of non-Laboulbenialean fungi on millipedes. Studies in Fungi 2(1): 130-137. https://doi.org/10.5943/sif/2/1/15

Fage L (1931) Araneae, 5e série, précédée d'un essai sur l'évolution souterraine et son déterminisme. In: Biospeologica, LV. Archives de Zoologie Expérimentale et Générale 71: 91-291.

Gama MM (1962) Collemboles des Grottes du Portugal. Voyage au Portugal du Dr. K. Lindberg. Boletim da Sociedade Portuguesa de Ciências Naturais 2 Sér, 9: 100-108.

Kime RD, Enghoff H (2017) Atlas of European millipedes 2: Order Julida (Class Diplopoda). European Journal of Taxonomy 346: 1-299. https://doi.org/10.5852/ejt.2017.346

Leach WE (1814) A tabular view of the external characters of four classes of animals, which Linné arranged under Insecta; with the distribution of the genera composing three of these classes into orders, etc. and descriptions of several new genera and species. Transactions of the Linnean Society of London 11(2): 306-400. https://doi.org/10.1111/j.1096-3642.1813. tb00065.x

Porat CO (1870) Om några Myriopoda från Azorerna. Öfversigt av Kongliga Vetenskaps. Akademiens Förhandlingar 1870(7): 813-823. [pl 10]

Read HJ (1989a) New species and records of the Cylindroiulus madeirae-group, with notes on the phylogenetic relationships (Diplopda, Julida: Julidae). Entomologica Scandinavica 19: 333-347. https://doi.org/10.1163/187631289X00212

Read HJ (1989b) The Cylindroiulus perforatus-group, with a description of a new species and notes on variation within C. perforatus Verhoeff, 1905 (Diplopda, Julida : Julidae). Entomologica Scandinavica 20: 243-249. https://doi.org/10.1163/187631289X00311

Read HJ (1990) The generic composition and relationships of the Cylindroiulini - a cladistic analysis (Diplopoda, Julida, Julidae. Entomologica Scandinavica 21: 97-112. https:/doi. org/10.1163/187631290X00085

Read HJ (1992) The genus Cylindroiulus Verhoeff 1894 in the faunas of the Caucasus, Turkey and Iran. Senckenbergiana biologica 72: 373-433.

Read HJ (1994) The millipede genus Cylindroiulus Verhoeff, 1894, in Middle Asia (Diplopoda Julida Julidae). Arthropoda Selecta 3(1-2): 117-132.

Read HJ (2005) A revision of the Cylindroiulus distinctus Lucas group from north Africa, with descriptions of six new species (Diplopoda, Julida, Julidae). Journal of Natural History 39(18): 1491-1532. https://doi.org/10.1080/0022293042000193689 
Read HJ (2007) The millipede genus Cylindroiulus Verhoeff, 1894 in north-west Spain and northern Portugal: recent records and descriptions of four new species (Diplopoda, Julida, Julidae). Graellsia 63: 279-294. https://doi.org/10.3989/graellsia.2007.v63.i2.95

Reboleira ASPS (2007) Cave beetles (Insecta, Coleoptera) of Estremenho karstic massif: an approach to its biodiversity. M.Sc. thesis. Department of Biology, University of Aveiro, 74 pp. http://hdl.handle.net/10773/721

Reboleira ASPS (2012) Biodiversity and conservation of subterranean fauna of Portuguese karst. PhD Thesis, University of Aveiro, 333 pp. http://hdl.handle.net/10773/10865

Reboleira ASPS, Gonçalves F, Serrano A (2009) Two new species of cave-dwelling beetles Trechus Clairville of fulvus-group in Portugal. Deutsche Entomologische Zeitschrift 56(1): 101-107. https://doi.org/10.1002/mmnd.200900009

Reboleira ASPS, Sendra A, Gonçalves F, Oromí P (2010) The first hypogean dipluran from Portugal: description of a new species of the genus Litocampa (Diplura: Campodeidae). Zootaxa 2728: 50-56.

Reboleira ASPS, Ortuño VM (2011) Description of the larva and female genitalia of Trechus gamae with data on its ecology. Bulletin of Insectology 64(1): 43-52.

Reboleira ASPS, Borges PAV, Gonçalves F, Serrano A, Oromí P (2011) The subterranean fauna of a biodiversity hotspot region - Portugal: an overview and its conservation. International Journal of Speleology 40(1): 23-37. https://doi.org/10.5038/1827-806X.40.1.4

Reboleira ASPS, Enghoff H (2013a) The genus Boreviulisoma Brolemann, 1928 - an Iberian-N African outlier of a mainly tropical tribe of millipedes (Diplopoda: Polydesmida: Paradoxosomatidae). Zootaxa 3646: 516-528. https://doi.org/10.11646/zootaxa.3646.5.2

Reboleira ASPS, Enghoff H (2013b) A new cave-dwelling millipede of the genus Scutogona from central Portugal (Diplopoda, Chordeumatida, Chamaesomatidae). Zootaxa 3736(2), 175-186. https://doi.org/10.11646/zootaxa.3736.2.5

Reboleira ASPS, Enghoff H (2014a) Millipedes (Diplopoda) from caves of Portugal. Journal of Cave and Karst Studies 76(1): 20-25. https://doi.org/10.4311/2013LSC0113

Reboleira ASPS, Enghoff H (2014b) Sireuma, a new genus of subterranean millipedes from the Iberian Peninsula (Diplopoda, Chordeumatida, Opisthocheiridae). Zootaxa 3785(1): 79-86. https://doi.org/10.11646/zootaxa.3785.1.6

Reboleira ASPS, Enghoff H (2014c) Insular species swarm goes underground: two new troglobiont Cylindroiulus millipedes from Madeira (Diplopoda: Julidae). Zootaxa 3785(3): 481489. https://doi.org/10.11646/zootaxa.3785.3.9

Reboleira ASPS, Enghoff H (2017) Subterranean millipedes (Diplopoda) of the Iberian Peninsula. Zootaxa 4317(2): 355-369. https://doi.org/10.11646/zootaxa.4317.2.10

Schubart O (1934) Tausendfüssler oder Myriapoda. I: Diplopoda. Tierwelt Deutchlands 28: $1-318$.

Silvestri F (1896) Una excursion in Tunisia (Symphyla, Chilopoda, Diplopoda). Naturalista Siciliano An. I (Nuova Serie) (8-12): 143-161. [pl 7]

Silvestri F (1932) Campodeidae (Thysanura) de Espana (primera parte). Eos 8: 115-164.

Vandel A (1946) Crustacés isopodes terrestres (Oniscoïdea) épigés et cavernicoles du Portugal. Anais da Faculdade de Ciências do Porto 30: 135-427. 
Verhoeff C (1891) Ein Beitrag zur mitteleuropäischen Diplopoden-Fauna. Berliner entomologische Zeitschrift 36(1): 115-166. [4 pls]

Verhoeff C (1894) Beiträge zur Systematik und Anatomie der Iuliden. Versuch einer natürlichen Gruppierung derselben. Verhandlungen der Zoologisch-Botanischen Gesellschaft in Wien 44: 137-162. [2 pls]

Verhoeff C (1899) Beiträge zur Kenntnis paläariktischer Myriopoden. IX. Aufsatz: Zur Systematik, Phylogenie und vergleichenden Morphologie der Juliden und über sinige andere Diplopoden. Archiv für Naturgeschichte 65(1): 183-220.

Verhoeff C (1900) Beiträge zur Kenntniss paläarktischer Myriopoden. XIII. Aufsatz: Zur vergleichenden Morphologie, Phylogenie, Gruppen- und Art-Systematik der Ascospermophora. Archiv für Naturgeschichte 66(1): 347-402.

Verhoeff KW (1905) Anmerkungen zu den Tafelwerken von C. L. Koch, die Myriapoden und A. Berlese (F. Silvestri) Acari, Miriapodi e Scorpioni italiani. Zur Klärung einiger Diplopoden-Gruppen und über einen neuen Iuliden. Notizen zu einigen neueren Arbeiten von C. Attems und übr zwei neue Polybothrus. Zoologischer Anzeiger 29(16): 497-514.

Wood HC (1864) Descriptions of new species of North American Iulidae. Proceedings of the Academy of Natural Sciences of Philadelphia 1864: 10-15. 